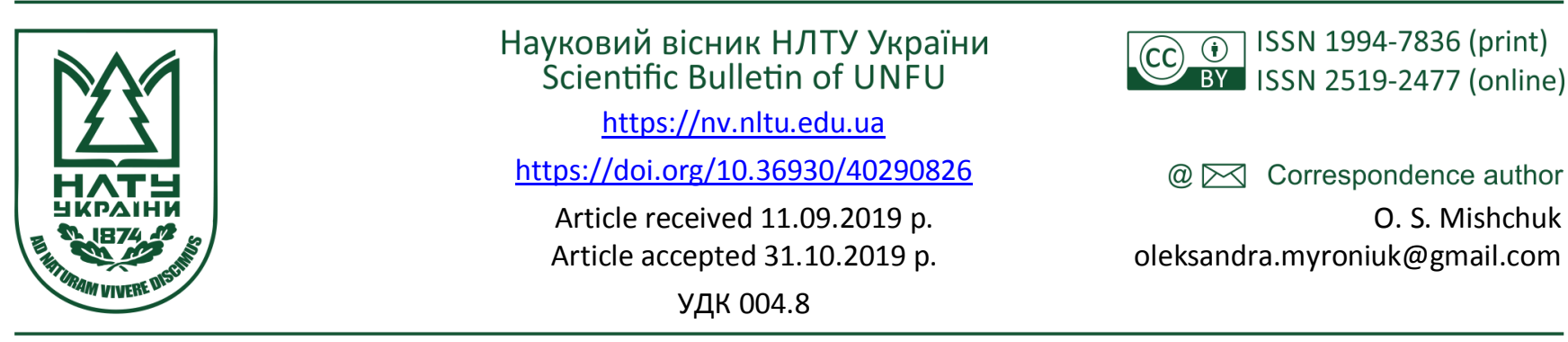

о. С. Мімук

Національний університет "Львівська політехніка", м. Львів, Украйна

\title{
БАГАТОКРОКОВЕ ПРОГНОЗУВАННЯ ТРЕНДУ ПОКАЗНИКІВ ЗАБРУДНЕННЯ АТМОСФЕРНОГО ПОВІТРЯ
}

\begin{abstract}
Наявність величезної кількості джерел небезпеки, спричинених діяльністю людини, становить реальну загрозу для самої людини і навколишнього середовища. Сучасний рівень організації та моніторингу забруднення навколишнього середовища висуває вимоги до розроблення нових підходів щодо вирішення проблеми контролю якості атмосферного повітря, прогнозування його забруднення та управління джерелами викидів шкідливих речовин на основі нових інформаційних технологій. Тому створення інтегрованих автоматизованих систем контролю та управління якістю атмосферного повітря, розроблення перспективних моделей і алгоритмів прогнозування забруднення повітря є актуальною проблемою. Одночасно розроблювані алгоритми прогнозування повинні бути простими та зрозумілими у використанні, тому у дослідженні описано та проаналізовано такі методи прогнозування параметрів забруднення атмосферного повітря: метод наївного прогнозу та методи прогнозування на основі лінійної нейроподібної структури моделі послідовних геометричних перетворень. Оскільки метод наївного прогнозу є найпростішим серед всіх наявних методів, було виконано порівняння методу прогнозування на основі лінійної нейроподібної структури моделі послідовних геометричних перетворень (НС МПГП) саме зі згаданим методом, 3 ціллю визначення який метод результує з кращими показниками. Експериментально доведено, що метод прогнозування тренду шкідливої домішки СО на основі лінійної нейроподібної структури моделі послідовних геометричних перетворень $\epsilon$ ефективним методом, оскільки показує точніші результати, ніж метод наївного прогнозу. Тому за допомогою розроблюваного методу виконано короткочасне багатокрокове прогнозування тренду забруднення атмосферного повітря.
\end{abstract}

Ключові слова: параметри забруднення; наївний прогноз; лінійні НС МПГП; горизонт прогнозування.

Вступ. Моніторинг навколишнього середовища - це інтелектуальна система з широким набором різноманітних модулів, що забезпечує збір і опрацювання інформації, отриманої в обраному просторово-часовому полі, подальшу інтерпретацію матеріалу, моделювання, прогноз і прийняття управлінських рішень. Частиною моніторингу навколишнього середовища $є$ екологічний моніторинг (Nychyk, 2011). Метою екологічного моніторингу (системи спостережень та контролю за станом навколишнього природного середовища) $є$ виявлення потенційних небезпек, розроблення заходів з охорони та запобігання можливості виникнення критичних ситуацій, шкідливих або небезпечних для здоров'я людей та для існування живих організмів. Основним завданням екологічного моніторингу $є$ спостереження за станом навколишнього середовища, оцінка і прогноз його стану, визначення ступеня антропогенного впливу на довкілля та виявлення чинників і джерел впливу (Zakon Ukrayiny, 1992).

Об'єктами екологічного моніторингу є довкілля та його елементи, зокрема повітря. Оцінювання екологічних наслідків техногенного впливу на повітряне середовище проводять за даними його моніторингу. Моніторинг забруднення атмосферного повітря дає характеристику на певний період часу екологічному стану по- вітряного середовища та прогноз розвитку цього стану. Функцією прогнозування стану атмосферного повітря $\epsilon$ розпізнавання тенденцій і логіки розвитку зміни цього стану. Отже, прогнозування покликане створити базу для прийняття оптимальних управлінських рішень. Інформаційний блок забезпечує формування екологічної інформації, котра потрібна для повного обгрунтування керівних рішень (Stepyko \& Barkov, 2002), наприклад для рішень щодо обмеження руху транспорту на ділянці, де прогнозовано зростання показників забруднення атмосферного повітря.

Мета роботи - виконати багатокрокове прогнозування тренду забруднення атмосферного повітря та визначити горизонт прогнозування. Для цього потрібно розробити метод прогнозування часових рядів за допомогою нейроподібних структур моделі послідовних геометричних перетворень та виконати загальноприйняте порівняння розроблюваного методу 3 методом наївного прогнозу.

Викладення основного матеріалу. Контроль за забрудненням навколишнього середовища має важливе значення для всього світу. Спеціально створена комісія в ООН втілює програму з контролю за забрудненням повітря (UNECE ICP Vegetation). Ця програма спрямована на визначення найбільш неблагополучних терито-

\section{Інформація про авторів:}

Міщук Олександра Сергіївна, аспірантка, кафедра інформаційних технологій видавничої справи.

Email: oleksandra.myroniuk@gmail.com; https://orcid.org/0000-0001-6823-985X

Цитування за ДСту: Міщук О. С. Багатокрокове прогнозування тренду показників забруднення атмосферного повітря. Науковий вісник НЛтУ України. 2019, т. 29, № 8. С. 142-146.

Citation APA: Mishchuk, O. S. (2019). Multi-step forecasting of trends of atmospheric air pollution indicators. Scientific Bulletin of UNFU, 29(8), 142-146. https://doi.org/10.36930/40290826 
рій, створення регіональних карт і кращого розуміння природи довгострокових транскордонних забруднень (Harmens \& Mills, 2014). Україна також докладає зусиль до моніторингу забруднення навколишнього середовища, не відстаючи від інших країн. Законом України "Про охорону навколишнього природного середовища" (ст. 20, 22) передбачено створення державної системи моніторингу довкілля та проведення спостережень за рівнем забруднення навколишнього природного середовища та загальним його станом (Zakon Ukrayiny, 1992). Виконавцем функцій цього закону є Міністерство природи та інші центральні органи виконавчої влади, які $є$ суб'єктами державної системи моніторингу довкілля, а також підприємства, установи та організації, діяльність яких призводить або може призвести до погіршення стану довкілля.

Державна гідрометеорологічна служба, що входить до складу МНС, здійснює спостереження за забрудненням атмосферного повітря у 53 містах України на 162 стаціонарних, двох маршрутних постах спостережень та двох станціях транскордонного переносу. Також вони ведуть спостереження за хімічним складом атмосферних опадів та за їх кислотністю. Обов'язковий моніторинг якості атмосферного повітря включає спостереження за сімома забруднювальними речовинами, серед яких: пил, двоокис азоту $\left(\mathrm{NO}_{2}\right)$, двоокис сірки $\left(\mathrm{SO}_{2}\right)$, оксид вуглецю, формальдегід $\left(\mathrm{H}_{2} \mathrm{CO}\right)$, свинець та бензапірен. Деякі зі станцій додатково здійснюють спостереження за іншими забруднювальними речовинами (Stepyko \& Barkov, 2002).

Отже, в місцях найбільшого забруднення атмосферного повітря розташовують спеціальні вимірювальні пости для моніторингу стану забруднення повітряного середовища. Наприклад, у Львові функціонують такі стаціонарні пости спостереження: 0401 - вул. Юнаківа; 0303 - вул. Городоцька, 211; 0704 - вул. Соборна, 11; 0808 - вул. Зелена, 301 (Pryrodni resursy, 2019). У Києві розташовано 16 стаціонарних постів, на котрих виконують спостереження за забрудненням атмосферного повітря 3 періодичністю відбору проб 6 днів на тиждень, 3-4 рази на добу. Центральна геофізична обсерваторія ім. Бориса Срезневського на офіційному сайті щотижня показує часткові результати моніторингу забруднення довкілля (Atmosferne povitria, 2019). Для досліджень було обрано стаціонарний пост спостереження у Києві, № 7 - Бесарабська площа.

Проведення аналізу та оцінки стану повітряного середовища мають особливо важливе значення для вибору оптимальних управлінських рішень, але вони грунтуються на використанні інформації, котра відображає теперішній i минулий стани. Цього для формування стратегії здебільшого буває недостатньо, тому потрібно врахувати тенденції забруднення атмосферного повітря, щоб виявити проблеми, з якими можна зіткнутися у майбутньому. Визначення тенденцій забруднення атмосферного повітря - відповідальний та складний процес, особливо в умовах нестабільності зовнішнього середовища (Dzendzeliuk, Liubun \& Rabyk, 2015).

Метою аналізу тренду є розкладання часового ряду на головні компоненти, вимірювання еволюції кожної компоненти в минулому і їі екстраполяція в майбутньому. Відзначку часу, до якої необхідно визначити майбутні значення часового ряду, називають горизонтом прогнозування, що визначає розмір тимчасового ін- тервалу, вираженого в одиницях прогнозу (години, дні, місяці і т.д.), для якого будується прогноз. Залежно від горизонту прогнозування, завдання прогнозування часового ряду зазвичай поділять на такі категорії терміновості: короткостроковий прогноз - від одного дня до місяця; середньостроковий прогноз - від одного місяця до року та довгостроковий прогноз - більш ніж на рік вперед (Skorokhoda et al., 2012).

Прогнозування забруднення за допомогою різних моделей ефективності можна розділити на три типи: потенційні прогнози, статистичні моделі та числові моделі. Для різних елементів воно поділяється на прогнозування потенціалу забруднення та прогнозування концентраціï (Dziuba et al., 2010). Прогноз концентрації безпосередньо прогнозує концентрацію забруднюючих речовин у певній області. Моделі прогнозування забруднення повітря можна поділити на параметричні та непараметричні. Параметрична модель полягає у визначенні параметрів рівнянь у відомій моделі, а її вихід невизначений. Наприклад, моделі, засновані на великій кількості історичних даних, таких як регресія, аналіз основних компонентів, тощо, зазвичай є параметричними моделями. Отже, однією 3 найпростіших моделей прогнозування, що використовуються на практиці, також $\epsilon$ регресійна модель (модель тренда). У ній залежною змінною виступає досліджуваний показник, а незалежною - час або номер спостереження цього показника. Тренд - це математичний опис тимчасової тенденції. Прогнозування з використанням трендів зводиться до підставляння необхідних номерів у майбутньому замість значення номера спостереження (або часу) (Skorokhoda et al., 2012).

Існує велика кількість підходів до прогнозування забруднення атмосферного повітря з використанням часових рядів за допомогою ШНМ. До них належать багатошарові перцептрони, нейронні мережі радіальних базисних функцій, рекурентні нейронні мережі та ін., всі 3 яких грунтуються на здатності апроксимувати нелінійні функції. Наприклад, у роботі (Schornobay-Lui et al., 2019) автори розробили прогностичні моделі забруднення повітря на основі статистичних даних за допомогою двох нейромережевих архітектур: багатошарової перцептронної та нелінійної авторегресивної екзогенної мережі. У роботі (Gokhale \& Khare, 2005) автори дослідили гібридну статистично-логістичну модель передбачення чадного газу. Дослідження (Rahman, Lee \& Latif, 2014) присвячено порівнянню сезонного авторегресивного інтегрованого ковзного середнього, штучної нейронної мережі та трьох моделей нечітких часових рядів за допомогою середньої абсолютної похибки та середньої квадратичної похибки. Виявлено, що точність моделей прогнозування за допомогою нейронних мереж вища, ніж у інших статистичних моделей (Schornobay-Lui et al., 2019; Gokhale \& Khare, 2005; Rahman, Lee \& Latif, 2014), але їх потрібно вдосконалювати. Отже, існує потреба у використанні нових моделей прогнозування для підвищення точності прогнозу іншими методами.

Оцінка точності прогнозування також має певну специфіку та особливості. Для оцінки точності прогнозування часових рядів дослідники використовують показники, що широко застосовуються в методах регресії, не пов'язаних з часовою залежністю. Після загально рекомендованого порівняння розроблюваних методів 3 
методом наївного прогнозу, отримавши достатньо малі величини похибок, можна стверджувати про досягнення високої точності прогнозів. Тому у роботі виконано дослідження нової моделі прогнозування на основі простих у налаштуванні та використанні лінійних нейронних структур моделі послідовних геометричних перетворень та порівняно розроблюваний метод з рекомендованим методом наївного прогнозу.

Матеріал та методи дослідження. Побудуємо короткочасний прогноз тренду концентрацій шкідливих речовин за інформацією про попередні значення концентрацій. Прогнозна нейронна мережа повинна мати всього один вихід і стільки входів, скільки попередніх значень необхідно використовувати для прогнозу, наприклад у дослідженні це 137 значень. Ці значення є показниками вимірюваними двічі на день згаданим раніше центром Срезневського (Atmosferne povitria, 2019). Для досліджень було взято стаціонарний пост номер 7 Бесарабська площа. Тут вимірюють такі показники: пил, хлористий водень, двоокис азоту, двоокис сірки, оксид вуглецю, фтористий водень, формальдегід.

У дослідженні розглянуто алгоритм прогнозування часових рядів на основі лінійної нейроподібної структури моделі послідовних геометричних перетворень (НС МПГП) (Izonin \& Tkachenko, 2019). НС МПГП при моделювання часових рядів забезпечують автоматичне розкладання часової послідовності на такі складові: тренд (тенденцію зміни) та коливання різної частоти, де сума всіх виділених складових дорівнює відлікам часового ряду. Враховуючи специфіку часових рядів, що описують зміни параметрів забруднення атмосферного повітря у часі, періодичні коливання, які спричиняються багатьма чинниками, практично не піддаються вірогідному прогнозуванню. Обсяг вхідного шару вибрано рівним розмірності вхідного вектора $x$. Кількість вихідних нейронів визначається кількістю прогнозованих періодів. Підбір кількості нейронів прихованого шару визначається практично методом підбору з настанням найбільш достовірного результату. Занадто велика їх кількість призводить до зростання похибки узагальнення.

Метод прогнозування тренду забруднення атмосферного повітря за допомогою нейронної структури МПГП містить такі пункти:

1. Створення окремих матриць значень для кожного відліку показників стаціонарного посту № 7, використавши методом ковзних часових вікон, де перші $n$ чисел рядка $\left(x_{1}, x_{2}, x_{3}, \ldots, x_{n}\right) \in$ вхідними значеннями нейронної мережі, а останнє число $(Y)$ - бажаний вихід нейронної мережі. значення якого дублюється з останнього значення входу $\left(x_{n}\right)$.

2. Виділення однієї головної компоненти та навчання лінійної нейроподібної структури МПГП на створених вибірках з дубльованими як додаткові входи виходами.

3. 3 отриманих під час навчання виходів для кожного параметра знову формуються матриці для різної кількості часових вікон.

4. Сформовані матриці розділяються на навчальну і тестову.

5. Застосування нейроподібної структури МПГП на матрицях з різною кількістю часових вікон для однокрокового прогнозування забруднення повітря.

6. Визначення числа часових вікон, при якому результати прогнозування $є$ найточнішими за допомогою розрахунку похибок прогнозування.

7. Виконання прогнозування тренду забруднення повітря методом наївного прогнозу.
8. Порівняння методу на основі НС МПГП з методом наївного прогнозу для підтвердження, що розроблюваний метод показує кращі результати прогнозування, а тому $\epsilon$ сенс у його використанні.

9. Оскільки у попередньому кроці визначено, що метод прогнозування з використанням лінійної НС МПГП результує 3 кращими похибками, тому виконується багатокрокове короткочасне прогнозування.

10. Горизонт прогнозування визначається останнім знайденим показником, похибка прогнозування якого наближається до $10 \%$.

На рис. 1 зображено похибки прогнозування різних параметрів забруднення повітря для часового вікна $t_{i w}=10$, оскільки похибки, знайдені за допомогою лінійної нейроподібної структури МПГП, є найменшими саме для такого вікна.

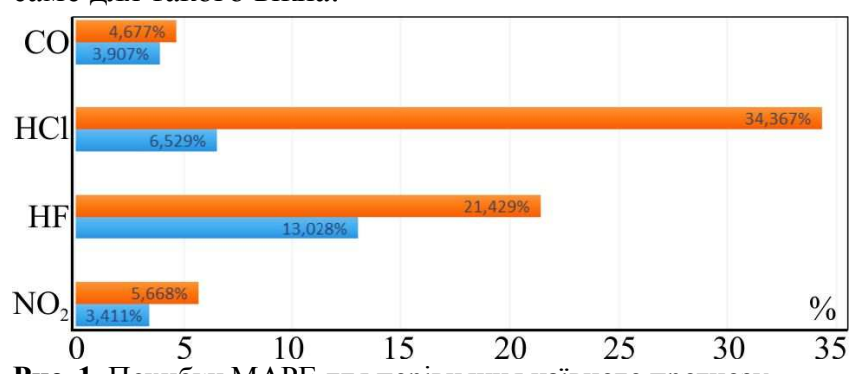

Рис. 1. Похибки МАРЕ для порівняння наївного прогнозу (оранжевий колір) з розроблюваним методом (синій колір)

Результати дослідження. У роботі спершу виконано однокрокове прогнозування показників оксиду вуглецю, хлористого водню, двоокису азоту та фтористого водню двома методами: наївного прогнозу та методом на основі лінійних НС МПГП. Як видно з рис. 1, позначені синім кольором похибки прогнозування розроблюваним методом $є$ меншими за похибки наївного прогнозу, котрі позначені оранжевим кольором. Оскільки розроблюваний метод виконується з точнішими результатами (див. рис. 1), тому за допомогою саме цього методу виконано подальше багатокрокове прогнозування згаданих параметрів забруднення атмосферного повітря. Для прикладу, на рис. 2 та 3 зображено результати багатокрокового короткочасного прогнозування тренду забруднення атмосферного повітря шкідливою домішкою СО для часового вікна 10.

У дослідженні використано дані спостережень за викидами шкідливих домішок двічі на день. Досягнувши 29-го показника тренду забруднення атмосферного повітря шкідливою домішкою СО похибка прогнозування перевищила межу $10 \%$ (Pohrebennyk \& Romaniuk, 2013). Тому горизонтом прогнозування вибрано два тижні (28 показників, тобто 14 днів), що задовольняє умову короткочасного прогнозування.

Висновки. У роботі описано важливість створення розширення та створення нових алгоритмів прогнозування забруднення навколишнього середовища для підвищення якості екологічного моніторингу. Порівняно та експериментально визначено, що розроблюваний метод на основі лінійних НС МПГП показує точніші результати прогнозування, ніж загально відомий простий метод наївного прогнозу, тому може бути використаний у подальших дослідженнях.

Виконано багатокрокове короткострокове прогнозування тренду забруднення атмосферного повітря на даних, отриманих зі стаціонарного посту моніторингу забруднення повітря в місті Києві. В результаті чого, 
визначено, що найкращі показники багатокрокового прогнозування за допомогою лінійної нейроподібної структури МПГП - для часового вікна 10, оскільки по- хибки прогнозування при такому вікні задовольняють потребам, і не перевищують допустимих меж.

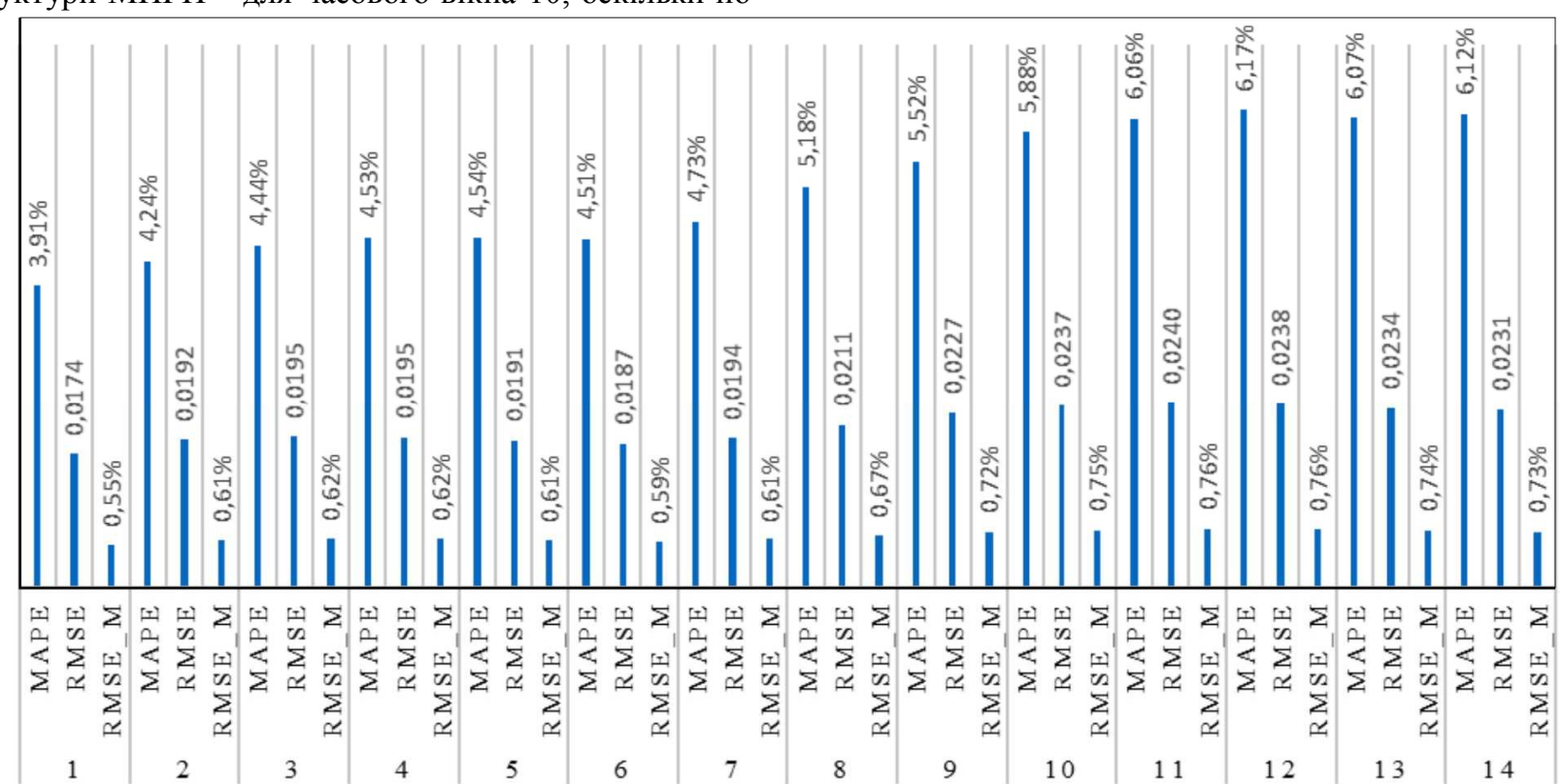

Рис. 2. Похибки прогнозування тренду забруднення СО на перший тиждень

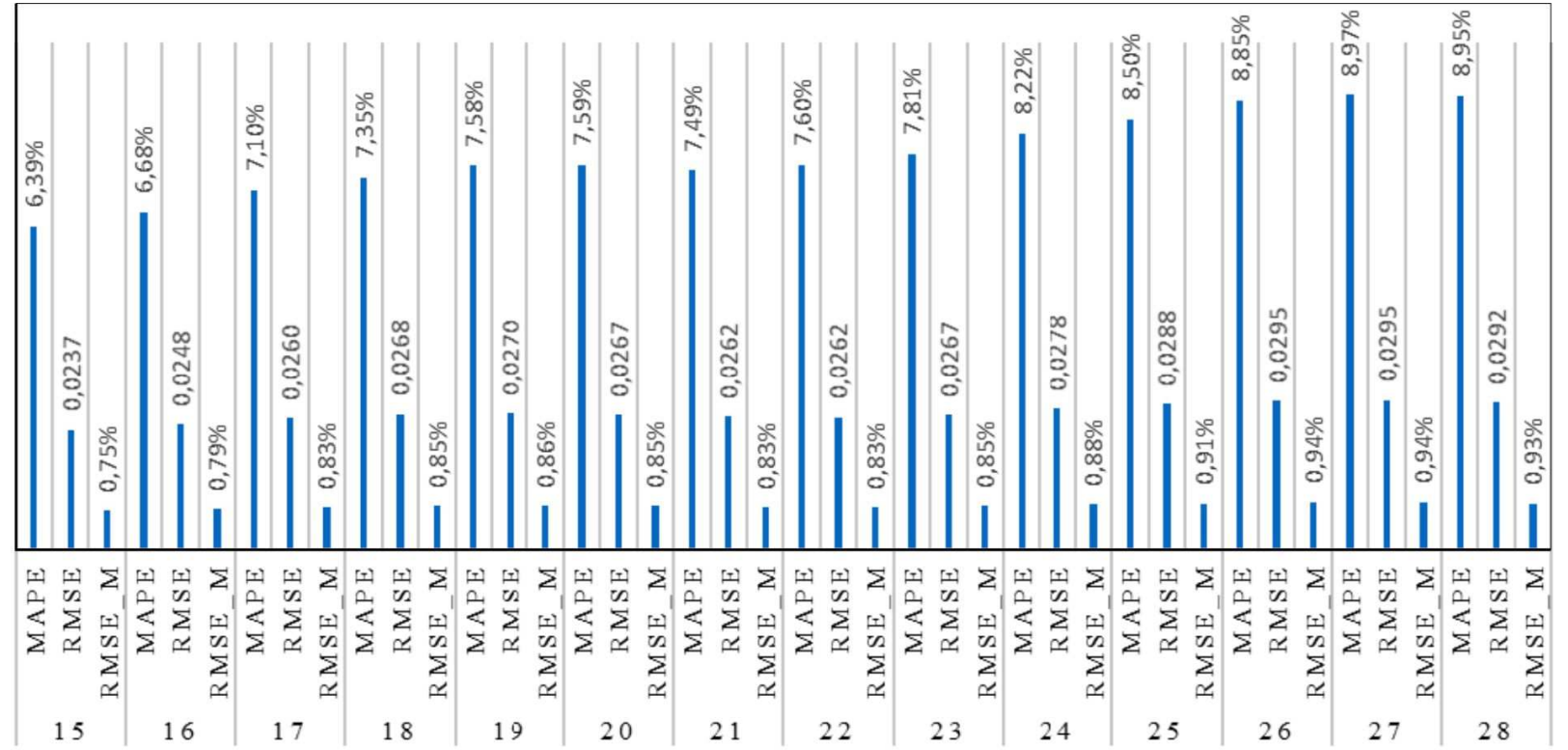

Pис. 3. Похибки прогнозування тренду забруднення СО на другий тиждень

Тренд даних часових послідовностей, вага якого в сумі складових є визначальною, як показали експерименти, достатньо точно прогнозований та надає уяву про загальний характер змін параметрів забруднення повітряного середовища у коротко- та середньостроковій перспективах.

\section{Перелік використаних джерел}

Atmosferne povitria. (2019). Sposterezhennia za zabrudnenniam atmosfernoho povitria $v \mathrm{~m}$. Kyievi. Retrieved from: http://cgosrez nevskyi.kiev.ua/index.php?fn=lsza\&f=lsza [In Ukrainian].

Dzendzeliuk, O., Liubun, Z., \& Rabyk, V. (2015). Prohnozuvannia parametriv dovkillia na osnovi shtuchnykh neironnykh merezh. Elektronika ta informatsiini tekhnolohii, 5, 102-113. [In Ukrainian]. Dziuba, S. M., Belianina, N. V., Prokopenko, M. N., \& Serovikov, S. A. (2010). Primenenie informatcionnykh tekhnologii dlia resheniia zadach ekologicheskogo monitoringa zagriazneniia atmosfery megapolisov. (Tematichnii vipusk: Informatika i modeliuvannia). Visnik Natcionalnogo tekhnichnogo universitetu "KhPI", 21, 58-65. [In Russian].
Gokhale, Sh., \& Khare, M. (2005). A hybrid model for predicting carbon monoxide from vehicular exhausts in urban environments. Atmospheric Environment, 39(22), 4025-4040. https://doi.org/10. 1016/j.atmosenv.2005.04.010

Harmens, H., \& Mills, G. (Eds). (2014). Air Pollution: Deposition to and impacts on vegetation in (South)-East Europe, Caucasus, Central Asia (EECCA/SEE) and South-East Asia. Report prepared by ICP Vegetation, March 2014. ICP Vegetation Programme Coordination Centre, Centre for Ecology and Hydrology, Bangor. UK. $72 \mathrm{p}$.

Izonin, I. V., \& Tkachenko, R. O. (2019). Komitet neiropodibnykh struktur MPHP z polinomialnym rozshyrenniam vkhodiv dlia zadach Velykykh danykh. In V. S. Ponomarenko (Ed.), Informatsiina bezpeka ta informatsiini tekhnolohii. Kharkiv: TOV "DISA PLYuS", (pp. 187-201). [In Ukrainian].

Nychyk, O. V. (2011). Monitorynh dovkillia. Kurs lektsii dlia studentiv dennoi ta zaochnoi form navchannia (6.040106 - Ekolohiia, okhorona navkolyshnoho seredovyshcha ta zbalansovane pryrodokorystuvannia). Kyiv: NUKhT, 67 p. [In Ukrainian].

Pohrebennyk, V. D., \& Romaniuk, A. V. (2013). Kompiuterni vymiriuvalno-informatsiini systemy dlia operatyvnoho ekolohichnoho 
monitorynhu vodnoho seredovyshcha. Lviv: Publishing house of Lviv Polytechnic, 160 p. [In Ukrainian].

Pryrodni resursy. (2019). Departament ekolohii ta pryrodnykh resursiv Lvivskoi Oblasnoi Derzhavnoi administratsii. Retrieved from: http://deplv.gov.ua/analitichna-dov [In Ukrainian].

Rahman, N. H. A., Lee, M. H., \& Latif, M. T. (2014). Artificial neural networks and fuzzy time series forecasting: an application to air quality. Quality and Quantity, 49(6), 2633-2647.

Schornobay-Lui, E., Alexandrina, E., Aguiar, M., Hanisch, W., Corrêa, E., \& Corrêa, N. (2019). Prediction of short and medium term PM10 concentration using artificial neural networks. Management of Environmental Quality, 30(2), 414-436.
Skorokhoda, O. V., Andriietskyi, B. R., Tsmots, I. H., \& Tkachenko, R. O. (2012). Zasoby otsiniuvannia parametriv dynamichnykh obiektiv na osnovi neiromerezhevoho synhuliarnoho spektralnoho analizu. Scientific Bulletin of UNFU, 22(11), 362-369. [In Ukrainian].

Stepyko, M. T., \& Barkov, Yu. Yu. (2002). Stratehichnyi prohnoz yak obiekt doslidzhennia. In O.S. Vlasiuk (Ed.), Stratehii rozvytku Ukrainy: teoriia i praktyka. Kyiv: NISD, pp. 38-50. [In Ukrainian].

Zakon Ukrayiny. (1992). Pro okhoronu atmosfernoho povitria vid 16.10.1992 p., № 2707-KhII (u chynnii redaktsii vid 18.12.2017). Vidomosti Verkhovnoi Rady Ukrainy, 50, 678. [In Ukrainian].

\section{O. S. Mishchuk}

Lviv Polytechnic National University, Lviv, Ukraine

\section{MULTI-STEP FORECASTING OF TRENDS OF ATMOSPHERIC AIR POLLUTION INDICATORS}

The presence of a large number of man-made sources of danger poses a real threat to humans and the environment. The current level of organization and production management puts forward the requirements of developing new approaches to the problem of air quality control, forecasting of its pollution and management of industrial sources of emissions of harmful substances based on new information technologies. The environmental impact of man-made environmental impact is assessed based on monitoring data, designed to characterize the environmental status of the environment and to forecast the development of the environment. The environmental prediction unit performs functions, recognition of trends, and logic of development of change of this state. Ultimately, forecasting is intended to create a basis for making optimal management decisions. The information block provides the generation of environmental information necessary to fully substantiate these management decisions. Therefore, the creation of integrated automated air quality control and management systems, the development of promising models and algorithms for predicting air pollution is a pressing problem. Simultaneously, the forecasting algorithms should be simple and understandable to use, so the study describes and analyzes the following methods for predicting air pollution parameters: the naive prediction method and the prediction methods based on the linear neural structure of a model of sequential geometric transformations. Since the naive prediction method is the simplest of all existing methods, a comparison of the prediction method based on the linear neural structure of the sequential geometric transformation model (SGTM) with that method was performed to determine which method results in better performance. It is experimentally proved that the method of predicting the trend of $\mathrm{CO}$ impurity based on the linear neural structure of the model of successive geometric transformations is effective because it shows more accurate results than the naive forecast method. Therefore, using the developed method, short-term multi-step forecasting of the trend of atmospheric air pollution was performed.

Keywords: pollution parameters; naive prognosis; linear SGTM neural-like structures; forecasting horizon. 